\title{
Carbonatitic to hydrous-silicic growth medium of diamonds from Internatsionalnaya kimberlite pipe (Yakutia)
}

\author{
D.A. Zedgenizov ${ }^{1}$, D. Araujo ${ }^{2}$, A.L. Ragozin ${ }^{1}$, V.S. Shatsky ${ }^{1}$, H.Kagi ${ }^{3}$, W.L. Griffin ${ }^{2}$ \\ ${ }^{1}$ Institute of Geology and Mineralogy, 3 Koptyuga ave., Novosibirsk, 630090, Russia \\ ${ }^{2}$ GEMOC ARC National Key Centre, Macquarie University, NSW 2109, Australia \\ ${ }^{3}$ Geochemical Laboratory, Graduate School of Science, University of Tokyo, Tokyo 113-0033, Japan
}

Diamonds are pristine time capsules from Earth's mantle. Microinclusions in natural diamonds represent a bulk sample of high-density fluids/melts (HDFs) from which they are crystallized (e.g. Navon et al., 1988), and provide a unique opportunity to characterize diamond-forming HDFs and to understand their origin and evolution within the mantle. Here we report the compositions of micro-inclusions in 44 fibrous diamonds from the Internatsionalnaya kimberlite pipes located in the central field of the Yakutian diamond province. The compositions of HDFs from Internatsionalnaya diamonds fall on the carbonatitic to hydrous-silicic join. This compositional range is reported here for the first time in Yakutian diamonds. We also address the question of the genetic relationship between these fluids and their host kimberlite magma.

The amount of major elements in the subsurface microinclusions has been determined using EDS. All analyses are normalized to $100 \%$ on a carbon -free basis (with excess oxygen for chlorine). Major- and trace-element compositions of the bulk microinclusion populations have been quantitatively analyzed by LAICP-MS. The abundance of carbonates, water and silicates in the diamonds were determined by FTIR. Additionally Raman spectroscopy has been used for phase identification in individual microinclusions. The nitrogen defect abundance and aggregation state of studied diamonds were calculated from FTIR spectra. The isotopic composition of carbon of some diamonds was measured using a continuous flow isotopic ratio mass spectrometer attached to a high temperature elemental analyzer.

The diamonds studied here are opaque due to abundant microinclusions and look grey in the rough. The proportion of such diamonds in the whole diamond population from Internatsionalnaya is high (up to 5\% of examined collections). Most of them have irregular roughly cubic shapes decorated by repetition of small octahedral faces (Fig.1 a). Some crystals have typical resorption features, such as the rounding of edges and etch-pits. The samples were polished into plates with a thickness of $100-200 \mu \mathrm{m}$. The polished plates are colorless. Most display an inner zone of high inclusion density and an outer inclusion-free rim (Fig. 1 b).
Central cubic diamonds reveal fibrous internal texture defined by trains of microinclusions. The outer transparent parts of many diamonds are not fibrous: CL patterns show layered octahedral growth (Fig. 1 c, d).
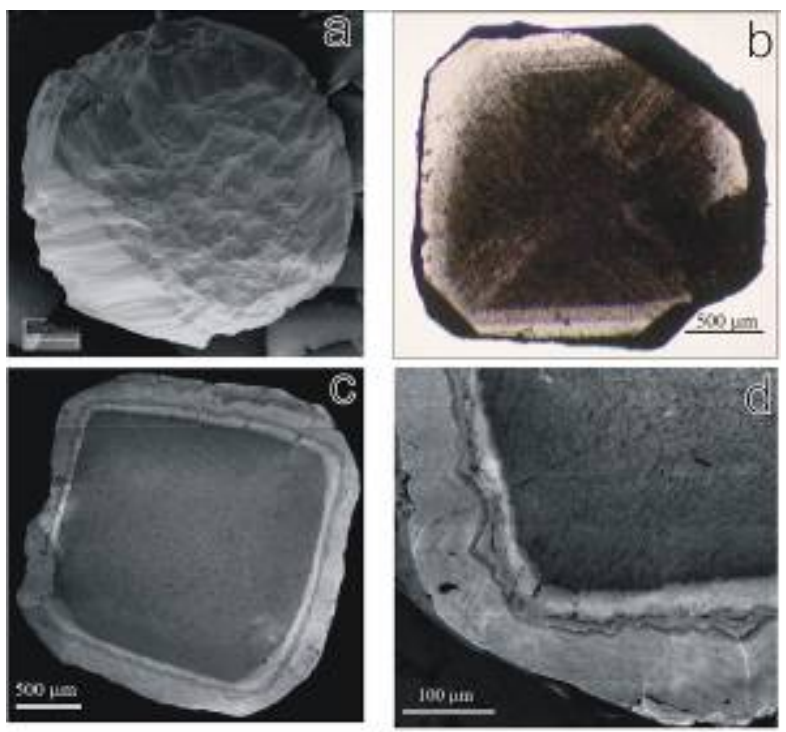

Fig. 1 Diamonds from Internatsionalnaya kimberlite pipe: (a) SEM image of diamond morphology; (b) polished plate with abundant microinclusions in the central part; (c) CL image of polished plates with zonal structure; (d) detail of (c) .

The bulk nitrogen concentration in the studied diamonds ranges between 35 and $1438 \mathrm{ppm}$. The typical range for 31 diamonds is between 200 and 850 ppm and averages $450 \mathrm{ppm}$. The 20 studied diamonds are of type IaA and 21 are of type IaAB with IaB/IaA ratio from 4 to $30 \%$.

The carbon isotope composition has been analyzed for 12 diamonds. The total range of $\delta^{13} \mathrm{C}$ of the studied diamonds is very narrow from -4.5 to $-6.5 \%$ o. The average value of $\delta^{13} \mathrm{C}$ for studied diamonds from Internatsionalnaya is exactly same as the average mantle -5.5 \% (Galimov, 1983). Figure 2 shows the correlation of carbon isotope composition and water/carbonate ratio of microinclusions. The carbonate-rich samples have a lighter carbon isotope 
composition than is observed in diamonds with lower carbonate content.

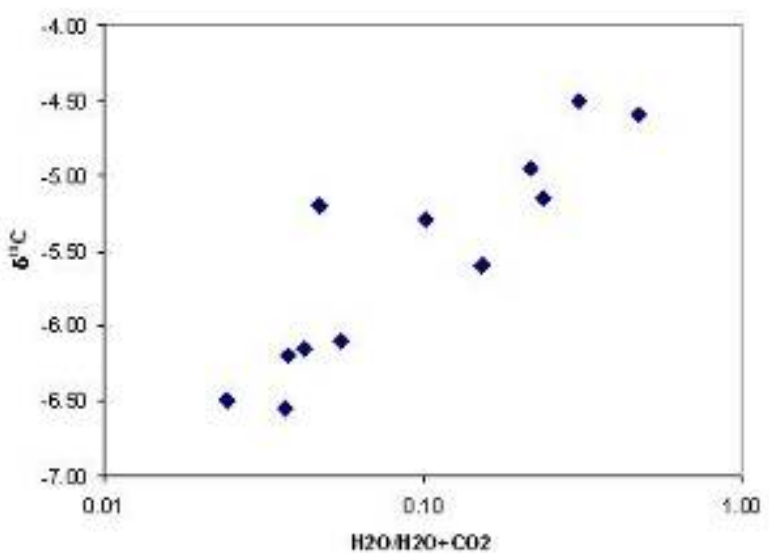

Fig. 2 Variations of water/carbonate ratio $\left(\mathrm{H}_{2} \mathrm{O} /\left(\mathrm{H}_{2} \mathrm{O}+\mathrm{CO}_{2}\right)\right)$ of microinclusions with carbon isotope composition of host diamonds from Internationalnaya kimberlite pipe.

The integrated IR and Raman spectroscopic investigations have revealed a multiphase assemblage of microinclusions in diamonds from Internatsionalnaya. The most common IR bands in the studied diamonds are those of water, carbonate and silicates. The relative amounts of these species depend on the sample. As in fibrous diamonds from other localities, some of our samples also show absorption by quartz and apatite. Rarely, weak absorption by $\mathrm{CO}_{2}$ molecules is observed. Raman spectroscopy has revealed the presence of carbonates, olivine, apatite, rutile and graphite.

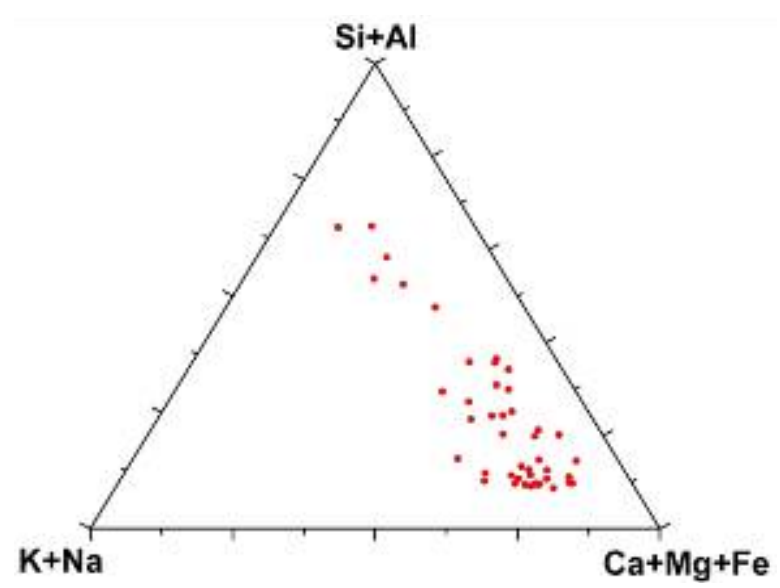

Fig. 3 Compositional variation of microinclusions in diamonds from Internatsionalnaya kimberlite pipe. Each point is the mean of data from an individual diamond.

The microinclusions in the studied diamonds have wide compositional variations. Some important correlations between silica and chlorine contents and the water/carbonate ratio of the microinclusions are observed. Water content generally correlates with the $\mathrm{SiO}_{2}$ concentration. At relatively constant $\mathrm{Ca} / \mathrm{Mg}(0.2-$ 0.4 , microinclusions show significant variations in $\mathrm{Fe}$ content (Mg\# 0.02-0.8). In comparison with the modern worldwide database most of the studied diamonds from Internatsionalnaya define a continuous range of carbonatitic to hydrous-silicic compositions and only few fall into the lower end of the carbonatitic to saline range (Fig. 3). The hydrous-silicic endmembers are rich in water, $\mathrm{SiO}_{2}, \mathrm{Al}_{2} \mathrm{O}_{3}, \mathrm{~K}_{2} \mathrm{O}$ and $\mathrm{P}_{2} \mathrm{O}_{5}$. Carbonatitic microinclusions are rich in carbonate, $\mathrm{CaO}, \mathrm{MgO}$ and $\mathrm{FeO}$. Samples with saline component are slightly enriched in water, $\mathrm{K}_{2} \mathrm{O}, \mathrm{Na}_{2} \mathrm{O}$ and $\mathrm{Cl}$.

Figure 4 presents the trace-element abundances of micro-inclusions in diamonds from Internatsionalnaya compared to the average composition of host kimberlite (Kostrovitsky et al., 2007) and an average carbonatite (Woolley, Kempe, 1989). The bulk analyses of the microinclusions have smooth patterns for the LILE, normalized to a primitive mantle composition. Some samples show enrichment in Cs. Some samples with hydrous-silicic compositions are depleted in Sr compared to those rich in carbonates. The relative abundance of $\mathrm{K}$ in the fluids is significantly higher than observed in the host kimberlite and carbonatites. The pattern of HFSE in the micro-inclusions shows some depletion in $\mathrm{Ti}, \mathrm{Zr}$ and Hf relative to $\mathrm{Ta}, \mathrm{Nb}$ and Mo. The REE pattern reveals low abundances of the heavy REE and high light REE concentrations. The La/Dy ratio of micro-inclusions varies widely, decreasing from carbonatitic to hydroussilicic compositions. Many samples with carbonatitic composition have a negative anomaly in Y. Diamonds from Internatsionalnaya have low contents of transition metals relative to other trace elements and most of them are significantly depleted in Ni and Co.

The trace-element compositions of the microinclusions are generally similar to those of kimberlites and carbonatites, but there are significant differences in major elements. The observed geochemical features are consistent with a genetic link between the diamondforming fluids and ephemeral carbonatitic liquids (fluids/melts) which sometimes may be precursors of the host kimberlite. These fluids/melts may originate either from the metasomatic influx of volatile agents or from partial melting of previously carbonated eclogites and peridotites. Some elemental variations may be explained by fractional crystallization of such fluids/melts, or mixing between liquids with different compositions. Schrauder and Navon (1994) suggested fractional crystallization as an explanation for the range of carbonatitic to hydrous-silicic compositions of fluid microinclusions in Botswanian diamonds: the precipitation of Ca-Mg carbonate, apatite and titanates from this fluid will drive the residual fluid composition towards more $\mathrm{H}_{2} \mathrm{O}$-rich compositions. This evolution may be responsible for carbon isotope fractionation as it observed in studied diamonds (Fig. 2). These fluids seem to be important for volatile and trace-element transport between mantle reservoirs and may also affect the stability of many mantle phases and facilitate melting. These processes may result in diamond formation and kimberlite generation. 

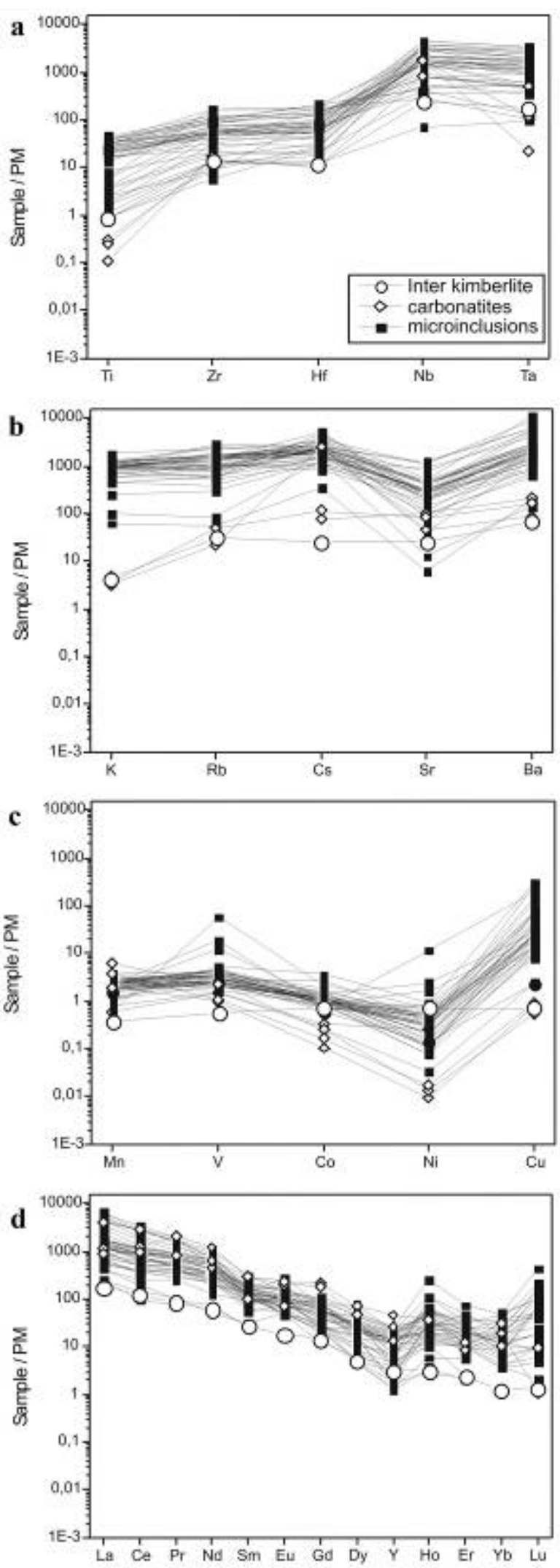

Fig. 5 Trace-element abundances of bulk microinclusions in Internatsionalnaya diamonds (black squares) normalized to Primitive Mantle values (McDonough, Sun, 1995). The abundances in the host kimberlite (open circles) and average carbonatites (open rhombs) are also shown.
This work was supported by the Council for grants of the President of Russian Federation (grant MK1613.2007.5) and by grants from the Australian Research Council.

\section{References:}

Navon, O., Hutcheon, I.D., Rossman, G.R., Wasserburg, G.J., 1988. Mantle-derived fluids in diamond microinclusions. Nature 335, 784-789.

Galimov, E.M., 1991. Isotope fractionation related to kimberlite magmatism and diamond formation. Geochimica et Cosmochimica Acta 55, 1697-1708.

Kostrovitsky, S.I., Morikiyo, T., Serov, I.V., Yakovlev, D.A., Amirzhanov, A.A., 2007. Isotope-geochemical systematics of kimberlites and related rocks from the Siberian Platform. Russian Geology and Geophysics 48, 272-290

Woolley, A.R., Kempe, D.R.C., 1989. Carbonatites: Nomenclature, average chemical compositions and element distribution. In: Carbonatites - Genesis and Evolution (ed. K.Bell), Unwin Hyman, 1-14.

Schrauder, M., Navon, O., 1994. Hydrous and carbonatitic mantle fluids in fibrous diamonds from Jwaneng, Botswana. Geochimica et Cosmochimica Acta 52, 761-771.

McDonough, W.F., Sun, S.-S., 1995. The composition of the Earth. Chemical Geology 120, 223-253. 